\title{
An Effective Learning Model to Support People Development: The Emerging Approach of The Hong Kong Institute for Vocational Education
}

\author{
Anita Sui Man Leung \\ Department of Business Administration \\ Hong Kong Institute of Vocational Education (Tsing Yi) \\ 20 Tsing Yi Road, NT, Hong Kong
}

Tel: 852-3757-9229Ｅ-mail: asmleung@vtc.edu.hk

Simon McGrath (Corresponding author)

School of Education

University of Nottingham

Jubilee Campus, Wollaton Road, Nottingham, NG8 1BB

Tel: 44-0115-951-4508 E-mail: simon.mcgrath@nottingham.ac.uk

\begin{abstract}
Globally, vocational and lifelong education reform now places greater stress on employability skills rather than only simple technical skills. This study undertakes a thorough review of the vocational education curriculum offered at one institution in Hong Kong so as to explore personal development opportunities that support the development of skills useful to both employability and broader personal development. Data was collected from multiple sources, including documents, questionnaires and interviews: a range of rich sources from different perspectives that explore the truth of students' personal development opportunities. The study findings indicate that personal development opportunities at the pilot institution are ineffective and a review of existing personal development training is recommended. More innovative new learning strategies should be introduced in and out of class activities to facilitate personal development for students. This study offers a practical guide regarding personal development for educators, and formulates an active learning model to support people development.
\end{abstract}

Keywords: Vocational education, Personal development, Active learning

\section{Introduction}

As part of the wider Hong Kong educational reforms aimed at promoting success in the global knowledge economy (Education Commission 2000), the system of vocational education and training is undergoing radical reform in the territory. To meet these new challenges, the introduction of a new structure, namely " $3+3+4$ ", to secondary and higher education in 2009 will require post-secondary level vocational programmes to respond. The Education Commission also recommends the provision of "a broad senior curriculum to enable students to acquire experiences in various key learning areas, construct a broad knowledge base and enhance their ability to analyse problems". (Education Commission 2000, p.100).

There has been little research into personal development education at the vocational training level and there remains a dearth of relevant research into a new personal development programme at the pilot institution. Data were collected in four phases. Phase one involved documentary research into relevant course content at higher diploma level offered at the pilot institution to identify key areas in personal development. Phase two involved quantitative research to identify the student competencies required in college. Phases three and four comprised qualitative study through semi-structured interviews with eight educators and six human resource practitioners to enhance the validity of data collected from the survey research and to explore further ideas.

\section{Meaning of Learning and Personal Development education}

What does learning mean? Joy-Matthews (2004) describes how the process of learning links 'outcome and processes'. Intended outcomes are individual goals; achieved outcomes lead to increased capabilities. Michael \& Modell (2003) address learning as changes in behaviour and cooperative learning models involving the student, peers and teachers to facilitate learning. Kolb \& Fry (1995) discuss experiential learning in formal and informal setting through reflection. (Kolb \& Fry, 1975 retrieved from infed). Although Kolb has developed more than one 
account of experiential learning over his career, pertinent here is the notion of experiential learning that explores and applies knowledge, and learning processes and skills in an immediate and relevant setting. This sort of learning is supported by a college or institute rather than being simply an informal process. Kolb \& Fry suggest that learners and learning can begin at any point of the learning cycle (see Figure 1).

Insert Figure 1 Here

Kolb and Fry argue that institutions need to ascertain where learners are at in the cycle and then intervene to support learning. Joyce and Calhoun (1996) describe how learning experiences are composed of content, process and social climate. (Joyce and Calhoun 1996, p.xi). Zimmerman et al. (1996) argue self-regulated learning is not something that can be done for students, it is something that is done by them. (Zimmerman et al. 1996, p.22).

How can learning apply to personal development? Sanford (1969) argues that learning is essentially about whole individual development as the individual interacts with their environment. Thus, education is about promoting this process.

He outlines some key elements of personal development:

(vi) Personal development involves "the organisation of increasing complexity", and thus is distinct from simple notions of "change" or "growth".

(vii) It involves the whole individual and their development: the intellect, emotions, and action are all inseparable and in interaction.

(viii) It is progressive: a succession of developmental changes takes place.

(ix) It reflects an interaction between the person and the environment.

(x) (cited in Hofer \& Pintrich, 2002, p.26)

Cotton (1995) notes how learning, competency and skills can become a part of personality and learners who achieve skills, competency and knowledge will incorporate this learning into their self-image. Personality is described by Cotton as "the characteristic patterns of behaviour, thought and emotion which determine the way a person adjusts to the environment". (Cotton, 1995, p.13).

Stevenson (2003) notes that "meta-cognition performs the function of organising, selecting and monitoring cognitive activity". (Campione et al. 1989; Jausovec 1994 cited in Stevenson 2003, p.173). With full support, students can become autonomous learners, regulating and developing their skills through reflection to develop into creative problem-solvers.

Noll (2009) argue that "learners control their learning and construct their new understandings through active engagement with the past and present experience through constructive approach".(Wm. Noll, 2009, p. 48-49). This approach can be adopted appropriately when the institution builds a sustainable constructive classroom culture and through major changes in curriculum, scheduling and assessment.

Guillaume, Yopp and Yopp (2007, p.3) argue that active learning for personal development requires active teaching:

Active teaching is an approach to instruction vigorously pursued by the teacher with the full intention to improve student learning and student control over that learning. Active teaching is characterized by clear purposes and is based on what the teacher knows about her particular students and about human learning and motivation. Active teachers modify instruction based on learners' reactions and mastery of new information and manage their classrooms to maximize student success.

Cotton (1995), Stern and Huber (1997), and Kember (2008) also emphasise active learning. Cotton suggests that through the use of learning support groups, individuals find assistance and encouragement as they work with others on the same learning tasks.

Michael and Modell discuss the provision of resources and the key role of the educator in developing new learning experiences:

The successful instructor must be psychic, anticipating every possible problem that students may have and preparing suitable learning experiences to address each of these problem....they must develop appropriate activities, along with supporting resource material, to meet all of these potential needs. Preparing for class must also include anticipating the unknown, an impossible task, and having solutions at hand for unknown problems... The questions that must be kept in mind are, "What problems do I anticipate my students will have when working with pertinent information?" and "What resources do I need to help the students recognize the problems they are having?" (Michael \& Modell, 2003, pp.44-45) 
Active learning methods discussed in this study encourage students to make decisions about their learning strategies, within the context of support groups and resources that support experiential learning. The active learning model can comprise action learning, project-based learning, flexible learning, collaborative learning, constructivism in learning, meta-cognition, self-regulated learning, problem-based learning, peer-assisted learning and experiential learning. These methods enrich the learning experience, and should be adopted in formal curriculum. They can also include extra-curricular activities so as to strengthen personal development.

\section{Review of Personal Development Education Curriculum at Pilot Institution}

Silberman (1990) suggests active teaching and learning methodologies can reinforce students' active learning experience. Therefore, course documents at the pilot institution were inspected in the academic year of 2004/2005. The modules which adopt active study strategies in teaching and learning were selected to identify what study strategies are integrated in the curriculum to facilitate learners. Four modules were identified as lying within the domain of personal education in business administration: Creativity, Action and Service (CAS); Integrated Studies (IS); Final Year Project (FYP); as well as the Student Attachment Programme (SAP). Whilst the optional SAP programme was 180 hours long, the three compulsory elements were 60 hours each. This was not sufficient to deliver all the competencies required. Detailed examination of student assessment revealed the following teaching strategies:

\section{Insert Table 1 Here}

Findings indicate that project learning is used across five different modules. By adopting different active learning models, a good supported learning atmosphere helps learners to develop key skills, as confirmed by the literature review (Sanford 1969; Stevenson 2003). Students learn how to cooperate with others through projects. Project work also enhances social and interactive skills; such skills constitute hidden learning outcomes. By taking the IS module, personal skills, self-reliance and interpersonal skills are acquired, as reflected in student evaluation. Regarding SAP, students are evaluated by external employers in nine areas: discipline, self-confidence, responsibility, work attitude, learning attitude, work competence, language proficiency, interpersonal relationships, and communication. The data revealed that $87 \%$ of employers rated students working as summer interns in 2004 (from the Business Promotion and Event Management) as excellent or good. Evaluation criteria were formed as skills indicators to be enhanced through internship.

In summary, the pilot institution adopted an integrated approach to personal development education through a modular approach, including extracurricular activities and workplace learning. Responses from students in the CAS module, and comments from employers regarding SAP were positive. Skills can be enhanced through group work, as noted in FYP and IS. Different teaching strategies are applied to deliver personal education, as discussed: learning in CAS, project-based learning in FYP, self-learning in IS and workplace learning in SAP.

\section{Stakeholder views}

Views regarding personal development curriculum and teaching strategies were collected from students, educators and human resource practitioners during the research period (December 2005 to July 2006).

\section{Views of students}

In the quantitative research phase, full-time students at the pilot institution were surveyed. A total of 146 structured questionnaires containing predetermined questions were delivered to students directly, eliciting 134 responses. These questionnaires were distributed to seven representative groups: Human Resource Management (HRM) at level 1; Business Information Systems (BIS group 1 \& 2); Corporate Administration and Systems (CAS) group at level 3; Final Year Project Group at Level 4 (Project Group); Academic Group from the Supplemental Instruction Programme (Academic Group). The questionnaires comprised fours parts. Part one involved a six-point Likert scale to assess satisfaction in college life. Findings indicate that students were not satisfied with personal development education provision. The second part of the survey enabled students to assess their own competencies. Students were invited to rank the top 10 competencies out of 21 competencies covering fundamental skills, personal management skills, teamwork skills, and skills extracted from the life skills module syllabus. The 18 key competencies were identified as follows:

Insert Table 2 Here

Numbers across the row generate indicate group preferences against a particular competency. Results indicated that using number (item 3), participating in projects and tasks (item 12), language proficiency - Cantonese (item 15), survival skills (item 19) and implementing change (item 21) garnered no responses. All groups believed that communication skills (item 1), problem solving (item 5) and English proficiency (item 15) constituted the top 3 most important competencies from a student perspective. 
Students were then asked to rank their top three methods that could be used in the Personal Development Programme (PDP). Across the seven groups, thirteen different training methods were suggested, as shown in Table 3. Frequency was calculated using the preference indicator (i.e. ${ }^{\mathrm{f}} / \mathrm{N}$ ) with the equation of frequencies (f) divided by number of responses $(\mathrm{N})$. The results were then ranked to provide an insight into students' preferred training methods. The results were as follows:

Insert Table 3 Here

Students indicated that action learning (item 5, 6 votes), small group tutoring (item 2, 4 votes), learning support (item 8,3 votes) and project learning (item 12, 3 votes) represented their preferred training methods to deliver personal development. In addition, students were invited to choose their preferred learning methods in the Personal Development Programme. A total of 127 out of 134 students (95\%) support the development of a programme to identify their learning needs. Students were asked to select their preferred structure as follows:

Insert Table 4 Here

According to an analysis of the data in Table 4, students themselves suggested the future shape or structure of the PDP by completing the questionnaire section 4.3, with choices as listed in Table 4. Open-end questions were used so students could express their views if necessary. A majority of students suggested that the programme should be organised in the form of workshops, and certificates were preferred to recognise student learning and achievement (A. Type, 75\%). Students suggested that the course should last one year (B. Duration, 44\%) and that there should be monthly supervisory meetings (C. Frequency of meeting, 51\%). Meeting should be conducted during weekdays (D. Days of Week, 70\%) and during school time (E. Meeting Time, 51\%). The department-in-charge should be the Student Affairs Office (F. Tutor/Person in charge, 28\%).

\section{Views of educators}

Firstly, educators were invited to comment on the existing personal development system. Six out of eight informants noted that students took formal modules (see Table 1). Some further activities also explored in interviews included the Enhancement programme offered by Student Affairs Office, the China Business Studies module, and other activities such as cross-border visits. The effectiveness of the existing programme was also discussed. Only two educators agreed with the survey findings on students' key competencies (as illustrated in Table 2). A Principal Lecturer involved in plans for a new personal development programme said that such a programme was a possible method to help students develop competencies and there should also be a focus on developing good attitudes:

The programme should not only focus on competency training, but also on helping students develop as an individual. Recognition by the employer is not an important issue, but it is most important that we train up our students to have a good attitude in learning and working. Once a good attitude is developed, students can be trained and develop competencies to contribute to workplace and the community. Lastly, I would like to point out that the PDP should be based on individual needs and aim to develop personal identity.

These comments were also supported by staff from the Student Affairs Office who emphasised that the programme should focus on developing 'quality'.

Three out of eight educators noted that certain skills might be difficult to incorporate in the formal curriculum, such as creative thinking, spoken English, and responsibility. There was agreement that informal learning was also important to develop skills. The findings show that a variety of training methods should be developed. A senior project officer and a training consultant provided further insights into competency-based training. They suggested that this method should be adopted in classroom learning or co-curricular activities. However, educators should understand that competencies must be clearly addressed to help students through learning. Performance indicators must be clear and transparent, and clearly linked to activities, where possible. A possible model is adapted from Murdock and Scutt's framework (2003, p.xxix) and involves 11 behavioral indicators to form a personal competency model (PCM) for business courses. As well as the PCM framework, the learning model should also integrate the pilot institution employability skills framework which covers three areas: fundamental skills (communication, managing information, numeracy, and problem solving); personal management skills (positive attitudes and behaviours, responsibility, adaptability, continuous learning, work safety); and teamwork skills (working with others and participating in projects and tasks). It is designed as a background personal competency framework for vocational students.

In summary, personal development is implemented formally in modules and informally through participation in extracurricular activities. Evidence here shows that the existing programme is too generalised and does not focus on personal needs. The majority of respondents say that training does not incorporate all competencies in the 
formal curriculum. Regarding pedagogy and curricula, it was agreed that informal learning is important in the development of skills. The possible model of personal competency model (PCM) can be adopted in teaching and learning so as to draw learners' attention in competency development and help learners develop the right attitude to learning.

\section{Views of human resource practitioners}

Firstly, recruitment was discussed. Prospective employers considered knowledge and competencies (including technical skills and soft skills) equally important overall. They also commented that students need all knowledge, skills and competencies to succeed in the modern job market. Through personal interviews with respondents, six interviewees identified 21 competencies as follows:

Insert Table 5 Here

Through detailed examination of the table above, we can see that only seven competencies are in common: communication skills, creativity, language proficiency, interpersonal skills, team spirit, willingness to learn, and problem solving. This suggests that competency levels at college are not sufficiently in line with employers' expectations. Educational institutions should review their programmes to narrow this gap.

In terms of training and development, one respondent suggested that experiential learning was one way to encourage students to expand their knowledge:

Skills can develop through experiential learning. As a professional human resource manager, I encourage staff to experience different situations through job rotation. By doing so, staff can familiarise themselves with frontline operations through hands on experience. Importantly, staff members not only learn about business in the most effective way, but also improve personal effectiveness and learn initiatively.

Teaching and learning methods were also explored through personal interviews. Project work, competency-based learning, task-based learning and action learning were discussed by three experts as follows:

Human Resource Manager: Your college could adopt project work in teaching and learning. This kind of learning is not just one-way, but includes, for example, role-playing exercises.

Human Resource Officer: In a classroom setting, communication skills, English speaking and working with others can reinforce project work. A lot of work can take place in groups and students should be made aware of performance indicators. Outside the classroom, extracurricular activities centered on task-based learning encourage responsibility and positive attitudes.

Human Capital Management Officer: I also believe adopting action and project work in teaching and learning are good methods to help students develop. It would also be beneficial if these activities are linked with the businesses. In addition, there should be a good variety of methods: different training workshop, placements and competition.

Learning strategies were also emphasised. A Human Capital Management Officer suggested that students should devise, with staff, their own self-development plans, that reflecting learned skills and self-assessed needs.

Regarding the structure of the PDP programme, five out of six respondents agreed with the findings of the student survey. Also, the PDP as a lifetime programme was explored:

The PDP can work as a lifetime programme. At the Chartered Institute of Personnel and Development (CIPD), learners are required to develop their conduct individual self-assessment in order to discover their training needs.

While students and educators strongly supported a formal personal development programme, employers argued that structure was not the crucial factor in successful personal development education. They also suggested that there was no single method or 'one size fits all' approach to personal development. The focus should be on developing students learning attitudes, nurturing independence and proactive learning. They also noted the added value of self-development through active participation in personal development activities: these are powerful learning techniques.

In summary, a wide variety of staff training methods was suggested to enhance skills, such as experiential learning. These methods can be delivered in an unstructured format. It was concluded that no single training method can inculcate all competencies. Teaching strategies include competency-based training, role-playing, action learning, and project work. It was also recommended that learning be based on personal effort, including self-assessment and proactive learning methods. The Chartered Institute of Personnel and Development learning model was recommended. Recognition of the programme by employers was not seen as the most pressing concern, nor was it seen as crucial in judging the success or not of the programme. The prime concern is the 
design of a programme relevant to students, and developing quality. Last but not the least, half of respondents agreed that a certificate should be presented to students, recognising their achievement in co-curricular participatory activities.

\section{Implications for Teaching and Learning Approaches}

Through the different stages of data collection, personal development opportunities to cope with change were discussed. Although different teaching strategies are adopted in teaching and learning, evidence suggests that improvement is needed in terms of contact hours, pedagogy and the development of market-driven courses to encourage creative thinking, problem solving, proactively and self-confidence in students. The findings indicate that students are aware of their needs and the demands of workplace. Students also suggested the future shape of the PDP. Moreover, the findings indicate that the majority of students do not have an aspiration in life, and that life balance and quality of life education should be integrated into the curriculum to develop awareness of broader life issues. Educators agreed on the need to review the existing personal development system and that competency-based training workshops should be offered to develop soft skills to support personal development. The Structured Whole Person Development (SWPD) programme will replace the existing system of personal development education from the AY 2007/2008 onwards. However, due to the limited number of hours allocated to the programme, there is insufficient time to deliver the skills that employers require. It is therefore necessary to develop co-curricular activities to improve personal and career development. Therefore, all activities (formal and informal) need to contribute to active learning through self-development and reflection. The following suggested workshops emerged from educators' comments, course documents, and teaching experience:

Insert Table 6 Here

Stakeholders suggest teaching guides, learning tools and the active learning model are necessary to support personal development through informal learning; these are new routes to successful learning and personal development. Learning tools, including a Personal Competency Model, a Personal Needs Survey, and a Personal Development Learning Plan, have been developed for this study.

\section{Teaching guide}

As noted by human resource practitioners, there is no single method suitable for all competencies. Educators need to identify the suitable training method for a particular co-curricular activity or programme. Different active learning models can be adopted. Applicable models, derived from this study, include action learning, flexible learning, collaborative learning, project work, competency based learning, peer-assisted learning, self-regulated learning, problem-based learning and constructivism in learning. The following questions are guidelines at the planning stage:

What are students' current needs (personal, financial, psychosocial, and career)?

What kinds of programme (or modules, activity) do colleges offer to students?

What alternative activities can we offer if we can't satisfy the students' needs?

What kind of active learning model should be adopted?

How can students be helped to reflect upon what they learn?

How can students be encouraged to learn independently and through peers?

Where can the programme to take place?

Who will be in charge of the programme and who will assess student performance?

Educators have to consider all the questions listed above - especially those relating to the availability of human and physical resources. Educators need to select active learning that is most relevant to the particular unit, course, activity or programme. Stern and Huber (1997, p.19) argue that "in more active forms of learning, learners make their own time plan, they choose learning goals and activities they like, they test their progress, they take care of learning and understanding on their own, and they reflect on errors and successes." Learning goals should be formulated to support self-development and good learning attitudes.

\section{Curriculum plan}

In curriculum design, concepts, knowledge, skills, attitude and self-development should be integrated into each co-curricular activity. In order to identify students' needs, educators should conduct a needs survey to determine the most appropriate project, task or activity to use. The following is an example curriculum design:

Insert Table 7 Here 


\section{Learning tools}

When planning a programme, it is important to understand student needs. A Personal Needs Survey (PNS) can be conducted. Stern and Huber (1997, p.75) note that "helping students become aware of their own role and possibilities in the learning process is the first step to increase students' responsibility and a way to reduce students' frustration." Through such a survey, students gain a deeper understanding of their needs, goals and take greater responsibility for their learning. Our target group - young people in their early twenties - may have a range of needs and concerns, such as personal issues, finance or career development. The four part form is designed to identify students' needs, strengths and weakness (parts I-III). Part IV is completed by the advisor or educator after discussion with students and provides a suggested personal development plan. Once students understand their goals, they will make greater effort to complete the programme. As a result, concepts, knowledge, skills and a good learning attitude will bolster personal development. The needs survey can form the basis of a suitable programme design. Furthermore, the Personal Competency Model and Personal Development Learning Plan were developed through this study. They can both be adopted as learning tools to support the development of competencies and leaning attitudes, through participatory co-curricular activities.

\section{Active learning strategies}

Three strategies were suggested by informants. Firstly, personal development education can be delivered in a structured format such as the SWPD. Secondly, as discussed by students and employers, formal training workshops can inculcate specific competencies relevant to the market. Thirdly, whilst employers note there is no single training strategy suitable for all aims, a general theme does emerge: the most powerful learning method is proactive self-development, as suggested by educators and employers. Teaching and learning strategies should focus on self-initiated activity, self-monitoring and self-evaluation. Students should take personal responsibility for learning, and develop positive, optimistic attitudes. Feedback, reinforcement and action are also important components (Barnes 1999, p.3).

\section{Conclusions and Recommendations}

This study is a case study at one institution and much of the evidence is attitudinal and relates to the very particular context of Hong Kong. Contextual factors mean that recommendations in this study cannot simply be assumed to be relevant to other settings. Nonetheless, we content that much of this case study is likely to be relevant to other settings. In this study, various suggestions were explored to support personal development education at vocational level. Key recommendations are as follows:

\section{Flexible Personal Development Programme}

To determine a suitable programme, a needs assessment should be conducted to help outline the content of a plan. This also supports the development of knowledge, skills and attitudes through active participation. Once a survey is conducted, performance standards, competency and behaviour indicators should be clear in the programme content. If resources are available, an information platform should be developed to upload relevant information for learners to use themselves. Learners can use this resource flexibly, and at their own pace. Extra-curricular activities and self-development and other personal development activities can be integrated into the formal curriculum. A suitable programme, like the Supplemental Instruction programme, can achieve a dual purpose: counseling training for leaders, and effective learning for members.

\section{Yearly programme with a main theme}

As developed at the Hong Kong Institute of Human Resource Management, a yearly programme with a main theme can be developed. Students register with the programme on a voluntary basis and submit documents at the end of the year to demonstrate their continuous learning. These documents can include personal competency inventories, needs surveys, Personal Development Learning Plans, a reflective learning journal, and a portfolio.

\section{Active learning}

A wide range of activities, including action learning, project work, flexible learning, collaborative learning, constructive in learning, self-regulated learning, peer-assisted learning and experiential learning can be integrated in co-curricular activities to support the development of skills through active participation. Competency-based learning can also be integrated into co-curricular curriculum design. The active learning model and competency-based learning are not commonly adopted in the existing system. However, they should be developed in the new personal development system to support the development of social and interpersonal skills and other employability skills.

\section{Student awards}

One way to motivate students to participate in co-curricular activities, and encourage achievement, is to 
implement an awards system involving formal certification in the final year. This kind of recognition is real and reinforces students' motivation and confidence. Competency in the form of performance and behaviour indicators should be acknowledged and documented, and these can be used by prospective employers.

\section{External support}

Outside resources are also important to support personal development education. Employers can participate in assessing students' performance and provide feedback on students' competency levels. All records should be kept in students' personal files. If possible, testimonial/reference letters should be issued by employers to recognise students' experiential learning during summer internships. Such extrinsic motivation can encourage student achievement, because an employer's reference is good for future job prospects. Nijhof and Brandsma $(1999$, p.11) also note that vocational education needs to be closely linked to employers, whilst at the same time preserving some autonomy. Employers can form business partnerships and advise providers on content and programme reviews.

\section{Learning environment}

Educators can create a good learning environment to support students intrinsically in their self-esteem, creating expectations to succeed, so students strive for success in study.

\section{Learning groups}

Group of 4-5 students can help students learn together. These groups develop trust and a good learning atmosphere, and maintain standards, thereby strengthen the learning process.

\section{Learning attitude and the individual}

'People factors' can affect learning. Students should develop such positive characteristics as noted by Gerson and Gerson (2006, p.40), good learning attitudes, perseverance and motivation. These characteristics of a rounded individual bolster lifelong learning. Lifelong learning augments personal development: it is a virtuous circle.

\section{Competency profile}

Specific competencies associated with a particular job must include relevant knowledge, skills (including technical and general skills) and attitude. Attitude is part of personal skills, and may seem obscure to students. Education institutions should educate students on the importance of personal skill to support lifelong learning.

\section{Teaching Guide}

Teaching guides, as suggested in discussion, should be designed for co-curricular activities and can include tools such as the needs survey and personal development learning plans. The needs survey focuses on student needs, strengths and weaknesses and also can help shape the design of programmes for students.

\section{Assessment Strategy}

A range of assessment tools can be adopted: reflective journals, peer evaluation, portfolios, objective tests, presentations, concept mapping and letters home. Educators can select the appropriate assessment methods for each scenario. Competency and behavioural standards should be made clear to students. In particular, reflective methods should be emphasised as this encourages good, proactive learning attitudes and participation.

\section{Staff Professionalism}

Staff should have the skills to apply competency-based and active learning models, to implement best teaching practice relevant to their disciplines and modules, and also have a clear commitment to the education and training industry.

\section{An Active Learning Model for Informal Learning}

This study formulates new teaching and learning strategies for informal learning to support individual development. An active learning model to develop people should comprise of seven components: teaching strategies, a personal development programme, learning strategies, learning process, learning implementation, learning attitude and learning outcomes. The following diagram illustrates the relationships between the seven components of active learning model:

Insert Figure 2 Here

\section{Stakeholders}

Developing positive learning attitudes to continuous learning is crucially important. Learning can take place both formally in class and informally. Stakeholders can enhance learning as follows: 
a) Training providers

A positive learning environment and policies should be developed by providers to create more learning opportunities and broaden students' horizons through experiential learning. Institutional culture should change to embrace the active learning model. In addition, the institution should forge partnerships with other organisations such as commercial firms, education providers, youth organisations and social enterprises to expand opportunities for students.

b) Employers

Employers can support the education sector through business partnerships and by providing placements. In addition, they can contribute to student assessment, and provide feedback on student learning at the workplace which can be used to evaluate the effectiveness of co-curricular activities and workplace learning more generally.

c) Educators

Educators should be good curriculum designers. In addition, they should help students to identify needs and personal goals, as evidence indicates students are motivated by goal setting. Students should be positively encouraged to learn intrinsically and good attitudes should be reinforced. Once students adopt positive attitudes to learning, they will strive to achieve their academic and personal goals. However, a balance needs to be struck: over-praising can seem insincere and patronising, whilst absence of praise is discouraging. An active learning model can also be used to develop learning and positive attitudes. Pedler (1991, p.166) argues that the teachers are shifting from being 'teacher-experts' to 'learning facilitators'.

d) Learners

To be effective learners, people should develop the ability to learn continuously and understand their strengths and weaknesses through reflection. Learners should take responsibility to learn instead of totally relying on the curriculum provided by the institution. In addition, positive learning attitudes should be developed. Positive learning attitudes open up broad fields of knowledge and skill sets, and bolster lifelong learning.

All around the world, good knowledge and appropriate skills are important. However, the modern job market demands even more; good attitudes and continuous proactive lifelong learning are now the keys to success. However, the importance of vocational learning goes further than this as it is, linked to arguments about active citizenship and full self-actualisation. The kind of programme outlined here has the potential to nurture fully rounded individuals. However, in Hong Kong, and elsewhere, the success of such programmes requires active collaboration by all relevant stakeholders.

\section{References}

Athanasou J. (2007). Evaluating Career Education and Guidance. Shannon Books: ACER Press.

Barnes R. (1999). Positive Teaching, Positive Learning. London and New York: Routledge.

Chapman D. \& Adams D. (2002). The Quality of Education: Dimensions and Strategies. Manila, Philippines: Asian Development Bank; Comparative Education Research Centre; The University of Hong Kong.

Cotton J. (1995). The theory of learners: an introduction. London: Kogan Page.

Education Commission (2000). Learning for Life, Learning through Life. Reform Proposals for the Education System in Hong Kong. Hong Kong: Government of the Hong Kong Special Administrative Region of The People's Republic of China.

Guillaume A.M., Yopp R.H. \& Yopp H. K. (2007). 50 Strategies for active teaching. Engaging K-12 learners in the classroom. Upper Saddle River: Pearson Education.

Hofer B. K. \&Pintrich P.R. (2002). Personal epistemology: the psychology of beliefs about knowledge and knowing. Mahwan and London: Lawrence Erlbaum.

Infed.(no date) David a. kolb on experiential learning. Retrieved on 26 August, 2006, from http://www.infed.org/biblio/b-explrn.htm

Joy-Matthews J., Megginson D. and Surtees M. (2004). Human Resource Development. London: Kogan Page.

Joyce B.R. \& Calhoun E.F.(1996). Creating learning experiences: The role of instructional theory and research. Alexandria, Virginia: Association for Supervision and Curriculum.

Kember D. (2008). Nurturing generic capabilities through a teaching and learning environment which provides practise in their use. Centre for Learning Enhancement And Research. The Chinese University of Hong Kong.

Leung A.S.M. (2008). The Effectiveness of Personal Development Opportunities at the Hong Kong Institute of 
Vocational Education (Tsing Yi). Unpublished EdD thesis: The University of Nottingham.

Michael J.A. \& Modell H.I. (2003). Active Learning in Secondary and College Science Classrooms. A Working Model for Helping the Learner to Learn. Mahwah, New Jersey: Lawrence Erlbaum.

Miles D.H. (2003). The 30-Second Encyclopedia of Learning and Performance: A Trainer's Guide to Theory, Terminology, and Practice. New York: American Management Association.

Murdock A. \& ScuttC. (2003). Personal Effectiveness ( $3^{\text {rd }}$ edition). Oxford: Butterworth, Heinemann.

Nijhof W.J. \& Brandsma J. (1999). Bridging the Skills Gap between Work and Education. Dordrecht: Kluwer.

Noll Wm. J. (2009). Thinking sides: Clashing Views on Educational Issues, $15^{\text {th }}$ edition. New York: McGraw Hill.

Pedler M. (1991). Action Learning in Practice. London: Gower.

Silberman M.L. (1990). Active Learning. A Handbook of Techniques, Designs, Case Examples and Tips. New York: Lexington.

Stern D. \& Huber G.L. (Eds.) (1997). Active Learning for Students and Teachers: Reports from Eight Countries. Frankfurt am Main: Peter Lang.

Stevenson J. (2003). Developing vocational expertise: principles and issues in vocational education. Crows Nest, N.S.W.: Allen \& Unwin.

Zimmerman B.J., Bonner S. \& Kovach R. (1996). Developing self-regulated learners: beyond achievement to self-efficacy. Washington, DC: American Psychological Association.

\section{Notes}

Note 1. The three learning tools used in this study are the Personal Competency Model, the Personal Needs Survey, and the Personal Development Learning Plan. They are available on request from Anita Leung Sui Man or Simon McGrath via e-mail: texsmal@nottingham.ac.uk or Simon.Mcgrath@nottingham.ac.uk

Table 1. Teaching methodologies to deliver personal education

\begin{tabular}{|c|c|c|c|c|c|c|}
\hline $\begin{array}{ll}\text { Teaching Methodologies } & \text { modules/activity }\end{array}$ & CAS & IS & FYP & Key Skills & Life Skills & SAP \\
\hline 1. Services learning & $\sqrt{ }$ & & & & & \\
\hline 2. Project learning & $\sqrt{ }$ & $\sqrt{ }$ & $\sqrt{ }$ & $\sqrt{ }$ & $\sqrt{ }$ & \\
\hline 3. Competency-based learning & & & $\sqrt{ }$ & $\sqrt{ }$ & $\sqrt{ }$ & \\
\hline 4. Task-based learning & & $\sqrt{ }$ & & & & \\
\hline 5. Workplace learning & & & $\sqrt{ }$ & & & $\sqrt{ }$ \\
\hline 6. Self-learning & $\sqrt{ }$ & & & & & \\
\hline
\end{tabular}

Table 2. Students' perceptions of key competencies

\begin{tabular}{|c|c|c|c|c|c|c|c|c|}
\hline Competency & $\begin{array}{l}\text { Human } \\
\text { Resource \& } \\
\text { Management } \\
\text { Level } 1 \\
\end{array}$ & $\begin{array}{l}\text { Business } \\
\text { Informatio } \\
\text { n System } \\
\text { Level } 2\end{array}$ & $\begin{array}{c}\text { Business } \\
\text { Information } \\
\text { system } \\
\text { Level } 2(\mathrm{Gp} 2)\end{array}$ & $\begin{array}{c}\text { Corporate } \\
\text { Administratio } \\
\text { n \& Systems } \\
\text { Level } 3 \\
\end{array}$ & $\begin{array}{c}\text { Project } \\
\text { Group } \\
\text { Level } 4\end{array}$ & $\begin{array}{l}\text { Academic } \\
\text { Level } 3\end{array}$ & $\begin{array}{c}\text { Leadership } \\
\text { Level } 3\end{array}$ & $\begin{array}{l}\text { Total no. in } \\
\text { Group } \\
\text { (Maximum 7) }\end{array}$ \\
\hline 1.Communication skills & 1 & 1 & 1 & 1 & 2 & 2 & 2 & 7 \\
\hline 2. Managing information & 5 & & & 4 & 6 & & & 3 \\
\hline 3. Using numbers & & & & & & & & $\mathbf{0}$ \\
\hline 4. Creative thinking & & & 7 & 6 & 7 & & 1 & 4 \\
\hline 5. Problem solving & 3 & 2 & 6 & 3 & 1 & 2 & 3 & 7 \\
\hline 6. Positive attitude & 5 & & 6 & 3 & & & & 3 \\
\hline 7. Positive behaviours & 5 & & & & 7 & & 5 & 3 \\
\hline 8. Responsibility & 4 & 2 & & 7 & 7 & 1 & 4 & 6 \\
\hline
\end{tabular}




\begin{tabular}{|c|c|c|c|c|c|c|c|c|}
\hline Competency & $\begin{array}{c}\text { Human } \\
\text { Resource \& } \\
\text { Management } \\
\text { Level } 1\end{array}$ & $\begin{array}{c}\text { Business } \\
\text { Informatio } \\
\text { n System } \\
\text { Level 2 } \\
\text { (Gp 1) }\end{array}$ & $\begin{array}{l}\text { Business } \\
\text { Information } \\
\text { system } \\
\text { Level } 2 \text { (Gp 2) }\end{array}$ & $\begin{array}{c}\text { Corporate } \\
\text { Administra } \\
\text { tion \& } \\
\text { Systems } \\
\text { Level } 3 \\
\end{array}$ & $\begin{array}{l}\text { Project Group } \\
\quad \text { Level } 4\end{array}$ & $\begin{array}{c}\text { Academic } \\
\text { Level } 3\end{array}$ & $\begin{array}{l}\text { Leadership } \\
\text { Level } 3\end{array}$ & $\begin{array}{l}\text { Total no. in } \\
\text { Group } \\
\text { (Maximum 7) }\end{array}$ \\
\hline 9. Continuous learning & 5 & & & & & 3 & & 2 \\
\hline 10. Working safely & 5 & 3 & & & & & & 2 \\
\hline 11. Work with others & & 1 & 4 & 3 & 4 & 4 & 1 & 6 \\
\hline $\begin{array}{l}\text { 12. Participating in } \\
\text { projects and tasks }\end{array}$ & & & & & & & & $\mathbf{0}$ \\
\hline 13. Interpersonal skills & 3 & & & & 7 & 3 & & 3 \\
\hline 14. Social skills & & 2 & 5 & 5 & & 4 & & 4 \\
\hline $\begin{array}{l}\text { 15. Language proficiency } \\
\text { - Cantonese } \\
\text { - English } \\
\text { - Putonghua }\end{array}$ & 2 & $\begin{array}{l}2 \\
3\end{array}$ & $\begin{array}{l}5 \\
8\end{array}$ & 2 & 5 & $\begin{array}{l}2 \\
4\end{array}$ & 5 & $\begin{array}{l}\mathbf{0} \\
7 \\
3 \\
\end{array}$ \\
\hline 16. Self improvement & & & 3 & & & 4 & 4 & 3 \\
\hline 17. Time management & & 2 & 2 & 7 & & 1 & 4 & 5 \\
\hline 18. Presentation skills & & 3 & & 4 & & & 5 & 3 \\
\hline 19. Survival skills & & & & & & & & $\mathbf{0}$ \\
\hline 20. Handling stress & & 3 & & & 3 & 4 & & 3 \\
\hline 21. Implementing change & & & & & & & & $\mathbf{0}$ \\
\hline
\end{tabular}

Table 3. Student choices of training methods in the PDP

\begin{tabular}{|c|c|c|c|c|c|c|c|c|}
\hline $\mathrm{P}_{\text {Training Methods }}^{\text {Course }}$ & $\begin{array}{l}\text { HRM } \\
\text { Level } 1\end{array}$ & $\begin{array}{l}\text { BIS } \\
\text { Level } 2 \text { (Gp 1) }\end{array}$ & $\begin{array}{l}\text { BIS } \\
\text { Level } 2 \text { (Gp 2) }\end{array}$ & $\begin{array}{l}\text { CAS } \\
\text { Level } 3\end{array}$ & $\begin{array}{l}\text { Project } \\
\text { Group } \\
\text { Level } 4\end{array}$ & $\begin{array}{l}\text { Academic } \\
\text { Level } 3\end{array}$ & $\begin{array}{l}\text { Leadership } \\
\text { Level } 3\end{array}$ & Frequency \\
\hline 1. Traditional lecturing & & & & & & & & $\mathbf{0}$ \\
\hline 2. Small group tutoring & 3 & & 1 & 3 & & & 1 & 4 \\
\hline $\begin{array}{l}\text { 3. Self-learning with independent } \\
\text { learning pack }\end{array}$ & & & & & & & & $\mathbf{0}$ \\
\hline 4. Summer training workshops & & & & 2 & 2 & & & 2 \\
\hline $\begin{array}{l}\text { 5. Action learning (work-related } \\
\text { projects). }\end{array}$ & & 1 & 1 & 1 & 1 & 1 & 2 & 6 \\
\hline $\begin{array}{l}\text { 6. Peer learning (Peer Mentorship } \\
\text { Programme) }\end{array}$ & & & & & & & & $\mathbf{0}$ \\
\hline 7. E-learning platform & & 2 & & & & & & 1 \\
\hline
\end{tabular}

\begin{tabular}{|l|l|l|l|l|l|l|l|l|}
\hline \multicolumn{1}{|c|}{ Course } & $\begin{array}{l}\text { HRM } \\
\text { Level 1 }\end{array}$ & $\begin{array}{l}\text { BIS } \\
\text { Level 2 (Gp 1) }\end{array}$ & $\begin{array}{l}\text { BIS } \\
\text { Level 2 (Gp 2) }\end{array}$ & $\begin{array}{l}\text { CAS } \\
\text { Level 3 }\end{array}$ & $\begin{array}{l}\text { Project } \\
\text { Group } \\
\text { Level 4 }\end{array}$ & $\begin{array}{l}\text { Academic } \\
\text { Level 3 }\end{array}$ & $\begin{array}{l}\text { Leadership } \\
\text { Level 3 }\end{array}$ & Frequency \\
\hline $\begin{array}{l}\text { 8. Learning with tutor and buddies } \\
\text { (e.g. Supplemental Instruction } \\
\text { Programme) }\end{array}$ & & & 2 & & 3 & $\mathbf{3}$ \\
\hline $\begin{array}{l}\text { 9. Learning with same counselor } \\
\text { assigned for 4 years }\end{array}$ & & & & & & 1 & $\mathbf{1}$ \\
\hline $\begin{array}{l}\text { 10. Individual tutored learning } \\
\text { with the same tutor for 4 years }\end{array}$ & 2 & & 2 & & & & $\mathbf{2}$ \\
\hline 11. Distance learning & & & & & & 3 & & \\
\hline 12. Project work & 1 & 3 & & & & 1 & $\mathbf{3}$ \\
\hline 13. Networking activities & & & & & $\mathbf{3}$ \\
\hline
\end{tabular}


Table 4. Students' views on the Structure of a Personal Development Programme

\begin{tabular}{|c|c|c|c|c|c|c|c|c|}
\hline & $\begin{array}{l}\text { HRM } \\
\text { Level } 1\end{array}$ & $\begin{array}{l}\text { BIS } \\
\text { Level } 2 \\
(\mathrm{Gp} \mathrm{1)} \\
\end{array}$ & $\begin{array}{l}\text { BIS } \\
\text { Level } 2 \\
(\mathrm{Gp} \mathrm{1)} \\
\end{array}$ & $\begin{array}{l}\text { CAS } \\
\text { Level } 3\end{array}$ & $\begin{array}{l}\text { Project Group } \\
\text { Level } 4\end{array}$ & $\begin{array}{l}\text { Academic } \\
\text { Level } 3\end{array}$ & $\begin{array}{l}\text { Leadership } \\
\text { Level } 3\end{array}$ & Average \\
\hline $\begin{array}{l}\text { A. Type: } \\
\text { - Workshop } \\
\text { - Informal Gathering }\end{array}$ & $\begin{array}{l}65 \% \\
35 \%\end{array}$ & $\begin{array}{l}95 \% \\
5 \%\end{array}$ & $\begin{array}{l}55 \% \\
45 \%\end{array}$ & $\begin{array}{l}86 \% \\
14 \%\end{array}$ & $\begin{array}{l}88 \% \\
12 \%\end{array}$ & $\begin{array}{l}67 \% \\
33 \%\end{array}$ & $\begin{array}{l}65 \% \\
35 \%\end{array}$ & $\begin{array}{l}75 \% \\
25 \%\end{array}$ \\
\hline $\begin{array}{l}\text { B. Duration: } \\
-6 \text { months programme } \\
-1 \text { year programme } \\
-2 \text { year programme } \\
- \text { Other ( } 3 \text { months) }\end{array}$ & $\begin{array}{l}44 \% \\
44 \% \\
12 \% \\
0 \% \\
\end{array}$ & $\begin{array}{l}55 \% \\
35 \% \\
10 \% \\
0 \% \\
\end{array}$ & $\begin{array}{l}26 \% \\
47 \% \\
16 \% \\
11 \% \\
\end{array}$ & $\begin{array}{l}55 \% \\
23 \% \\
13 \% \\
9 \% \\
\end{array}$ & $\begin{array}{l}47 \% \\
53 \% \\
0 \% \\
0 \% \\
\end{array}$ & $\begin{array}{l}33 \% \\
50 \% \\
17 \% \\
0 \% \\
\end{array}$ & $\begin{array}{l}35 \% \\
53 \% \\
6 \% \\
6 \% \\
\end{array}$ & $\begin{array}{l}42 \% \\
44 \% \\
11 \% \\
3 \% \\
\end{array}$ \\
\hline $\begin{array}{l}\text { C. Frequency of meeting: } \\
\text { - Once per month } \\
\text { - Two times per quarter } \\
\text { - Twice a year } \\
\text { - Others }\end{array}$ & $\begin{array}{l}44 \% \\
39 \% \\
17 \% \\
0 \%\end{array}$ & $\begin{array}{l}30 \% \\
50 \% \\
20 \% \\
0 \% \\
\end{array}$ & $\begin{array}{l}33 \% \\
56 \% \\
11 \% \\
0 \% \\
\end{array}$ & $\begin{array}{l}54 \% \\
23 \% \\
23 \% \\
0 \%\end{array}$ & $\begin{array}{l}73 \% \\
13 \% \\
7 \% \\
7 \%\end{array}$ & $\begin{array}{l}50 \% \\
50 \% \\
0 \% \\
0 \%\end{array}$ & $\begin{array}{l}71 \% \\
23 \% \\
0 \% \\
6 \%\end{array}$ & $\begin{array}{l}51 \% \\
36 \% \\
11 \% \\
2 \% \\
\end{array}$ \\
\hline $\begin{array}{l}\text { D. Days of Week: } \\
\text { - During weekdays } \\
\text { - During weekends- }\end{array}$ & $\begin{array}{c}64 \% \\
36 \%\end{array}$ & $\begin{array}{l}50 \% \\
50 \%\end{array}$ & $\begin{array}{l}71 \% \\
29 \% \\
\end{array}$ & $\begin{array}{l}62 \% \\
38 \%\end{array}$ & $\begin{array}{l}80 \% \\
20 \%\end{array}$ & $\begin{array}{l}83 \% \\
17 \%\end{array}$ & $\begin{array}{l}81 \% \\
19 \%\end{array}$ & $\begin{array}{l}70 \% \\
30 \% \\
\end{array}$ \\
\hline $\begin{array}{l}\text { E. Meeting Time: } \\
\text { - During school hours } \\
\text { - After school hours } \\
\text { - Combination of the above }\end{array}$ & $\begin{array}{l}61 \% \\
35 \% \\
4 \% \\
\end{array}$ & $\begin{array}{l}47 \% \\
47 \% \\
6 \% \\
\end{array}$ & $\begin{array}{l}28 \% \\
44 \% \\
28 \% \\
\end{array}$ & $\begin{array}{l}44 \% \\
26 \% \\
30 \% \\
\end{array}$ & $\begin{array}{l}33 \% \\
33 \% \\
34 \% \\
\end{array}$ & $\begin{array}{l}80 \% \\
20 \% \\
0 \% \\
\end{array}$ & $\begin{array}{l}64 \% \\
12 \% \\
24 \% \\
\end{array}$ & $\begin{array}{l}51 \% \\
31 \% \\
18 \% \\
\end{array}$ \\
\hline $\begin{array}{l}\text { F. Tutor / Person in charge: } \\
\text { - Academic staffs } \\
\text { - Students Affairs Officer } \\
\text { - Professional Counsellor } \\
\text { assigned by the department } \\
\text { - Professional Counsellor } \\
\text { assigned by the SAO } \\
\text { - Other Institute or Mentor }\end{array}$ & $\begin{array}{l}17 \% \\
39 \% \\
22 \% \\
22 \% \\
0 \%\end{array}$ & $\begin{array}{l}25 \% \\
35 \% \\
15 \% \\
25 \% \\
0 \%\end{array}$ & $\begin{array}{l}20 \% \\
35 \% \\
30 \% \\
15 \% \\
0 \%\end{array}$ & $\begin{array}{l}28 \% \\
40 \% \\
16 \% \\
16 \% \\
0 \%\end{array}$ & $\begin{array}{l}20 \% \\
10 \% \\
35 \% \\
25 \% \\
10 \%\end{array}$ & $\begin{array}{l}29 \% \\
14 \% \\
14 \% \\
43 \% \\
0 \%\end{array}$ & $\begin{array}{l}22 \% \\
22 \% \\
28 \% \\
17 \% \\
11 \%\end{array}$ & $\begin{array}{l}23 \% \\
28 \% \\
23 \% \\
23 \% \\
3 \%\end{array}$ \\
\hline
\end{tabular}

Table 5. Comparison of the competency requirements for college and at workplace

\begin{tabular}{|l|l|l|}
\hline & Competency required at College level & Competency required in selection (from employers' perspective) \\
\hline 1 & Communication skills & Communication \\
\hline 2 & Managing information & Customer focus \\
\hline 3 & Using numbers & Business understanding \\
\hline 4 & Creative thinking & Personal effectiveness \\
\hline 5 & Problem solving & Creativity \\
\hline 6 & Positive attitude & Service mindset \\
\hline 7 & Positive behaviours & Working experience \\
\hline 8 & Responsibility & Language proficiency \\
\hline 9 & Learn continuously & Outgoing and friendly \\
\hline 10 & Work safely & Analytical power \\
\hline 11 & Work with others & Interpersonal skills \\
\hline 12 & Participate in projects and tasks & Good team spirit \\
\hline 13 & Interpersonal skills & Knowledge \\
\hline 14 & Social skills & Independence \\
\hline 15 & Language proficiency & Professionalism \\
\hline 16 & Self improvement & Proactively \\
\hline 17 & Time management & Willingness to learn \\
\hline 18 & Presentation skills & Networking \\
\hline 19 & Survival skills & Leadership \\
\hline 20 & Handling stress & Problem solving \\
\hline 21 & Implementing change & Negotiation \\
\hline & & \\
\hline
\end{tabular}


Table 6. Co-curricular activities / Active Learning Model to be integrated into the SWPD

\begin{tabular}{|l|l|}
\hline Attributes from SWPD & Example of co-curricular activities / Active Learning Model in classroom learning \\
\hline 1. Team work & Teambuilding workshop, leadership workshop, mentorship scheme, collaborative learning, project work \\
\hline 2. Career development and work attitude & Workplace Attachment Scheme, company visits, flexible learning \\
\hline 3. Self confidence and EQ & Simulated interviews, EQ Workshop \\
\hline 4. Career and ethics & ICAC Workshop, Book reading scheme, Voluntary work, Action learning \\
\hline 5. Self, family, work and society & Community projects, family education, company visits, task-based learning, cross-border visits \\
\hline 6. Improving learning and performance & $\begin{array}{l}\text { Simulated performance appraisal workshops, Supplemental Instruction Programme, competency based } \\
\text { learning, learning new skills }\end{array}$ \\
\hline 7. Communication & Peer Mentorship Programme, group learning, presentation \\
\hline 8. Problem Solving & $\begin{array}{l}\text { Process restructuring workshop, workshop on crisis management, managing change workshop, } \\
\text { problem-based learning }\end{array}$ \\
\hline 9. Life Balance & $\begin{array}{l}\text { Networking workshop, social skills workshop, music appreciation party, Talk on spa / facial / physical } \\
\text { exercise / music to release stress, holiday experience sharing }\end{array}$ \\
\hline
\end{tabular}

Table 7. Curriculum design (for co-curricular activities)

\begin{tabular}{|l|l|}
\hline \multicolumn{1}{|c|}{ Suggestions } & \\
\hline Programme Title (Level) & Informal Learning Programme (for Year Two or Level Three students) \\
\hline Theme for the programme & To be a good coach to motivate learners' to learn effectively \\
\hline Hours involved & Ten hours face to face consultation and ten hours informal communication \\
\hline Programme aims & $\begin{array}{l}\text { 1. To help students become effective learners by enhancing their learning skills and spurring motivation and } \\
\text { interest in their studies. }\end{array}$ \\
& $\begin{array}{l}\text { 2. To increase students' psychological health through personal support. } \\
\text { 3. To develop a learning culture where student learn and grow together. }\end{array}$ \\
\hline Applicable active learning models & Collaborative learning and action learning \\
\hline Assessments Tools & Portfolio, reflective journal and personal development learning plan \\
\hline Co-curricular Learning Outcomes & Leadership skills and coaching skills \\
\hline Applicable professions & Social worker; Teacher; Counselor; Trainer \\
\hline
\end{tabular}

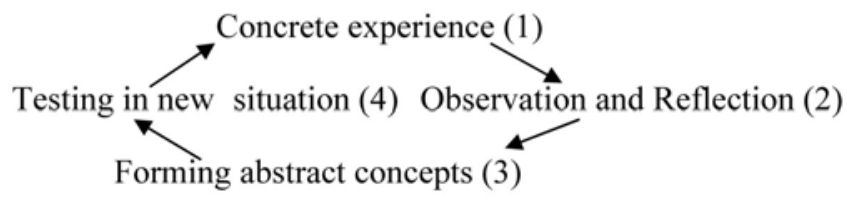

Figure 1. Kolb and Fry learning cycle

(Source: infed online resources: http://www.infed.org/biblio/b-explrn.htm)

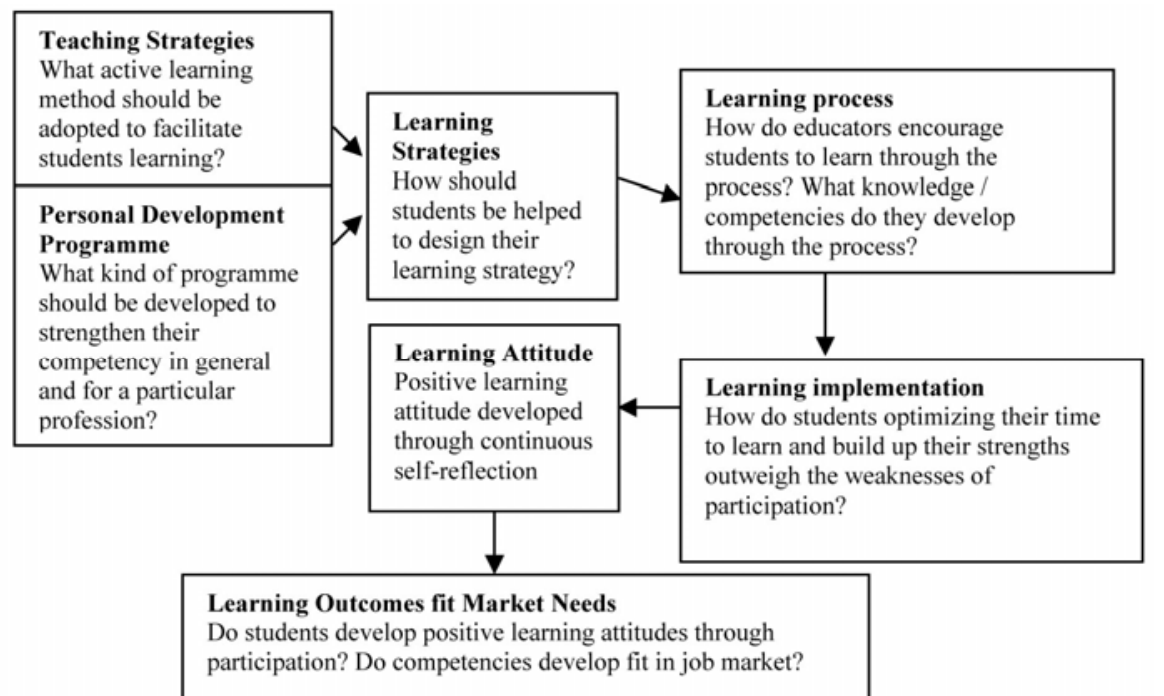

Figure 2. Modern strategies to develop people 